A. Krowiak

\title{
FEATURES OF THE RESOURCES OF THE HARD COAL COVERING IN THIN COAL-SEAMS IN POLAND
}

The results of analyses of features of geological resources of the hard coal, in majority of mine located in Poland, were presented, according to adopted arbitrarily criteria. All active mines of the hard in the Silesia voivodship were provided with analysis.

ОСОБЛИВОСТІ ЗАЛЯГАННЯ РЕСУРСІВ КАМ'ЯНОГО ВУГІЛЛЯ В ТОНКИХ ПЛАСТАХ у польщ।

Результати аналізів особливостей геологічних ресурсів кам'яного вугілля, в більшості шахт Польщі, були представлені згідно довільно прийнятим критеріям. Були проаналізовані всі діючі кам'яновугільні шахти воєводства Сілесія.

ОСОБЕННОСТИ ЗАЛЕГАНИЯ РЕСУРСОВ КАМЕННОГО УГЛЯ В ТОНКИХ ПЛАСТАХ В ПОЛЬШЕ

Результаты анализов особенностей геологических ресурсов каменного угля, в большинстве шахт Польши, были представлены согласно произвольно принятым критериям. Были проанализированы все действующие каменноугольные шахты воеводства Силесия.

\section{INTRODUCTION}

Described analysis concerns resources of the hard coal covering in active mines in Poland, located in the Silesian Voivodeship.

It is embracing almost $100 \%$ of all mines of the hard coal in Poland, apart from one mine "Bogdanka" in the Lublin Voivodeship. The Silesian voivodship is on the South of country. Coal seams are defined as the medium thickness from 0,6 up to $1,6 \mathrm{~m}$.

Over 10 billion ton of the hard coal covering in thin coal-seams are in resources of analysed mines. In Poland, over 30 years ago, it was resigned from their exploitation, having thicker seams at their disposal. It comes back to idea of exploitation of thin coal-seams at present, because thick seams in some mines undergo exhaustion, which threatens these mines the clo- sure with reason of exhaustion of resources.

It is a next argument for the return to the exploitation of thin coal-seams, that many of them, incurring little investments relatively, it is possible to exploit from mine horizon's already made available. Building new mineshafts and new levels of the output in mines is an alternative what requires very big investments.

This analysis concerns geological resources. On this stage of the works, associated with the identification of thin coal-seams, it isn't possible to settle which of them are already now available for the economically justified exploitation. It requires further research works and design. Nevertheless, accepting theoretically, that at least $10 \%$ of these resources are available, right away to efficient economical exploitation, we have over 1 billion the tone of coal at our disposal. It is An 
equivalent of 10 of year's production of the hard coal in Poland.

The analysis was carried out an analysis under the following criteria: type of coal, division into ranges of the average depth of covering of coal-seams, the division into ranges of the average inclination of seams, associative criteria of the average depth of covering and the medium thickness of seams and associative criteria for average depth of covering, the average of the calorific value and the average of contents of sulphur. Chosen criteria of diameters of analysis were chosen arbitrarily. The last diameter of analysis is being taken back to quality parameters of coal, taking into account its calorific value and the content of sulphur.

\section{METHOD OF ANALYSIS}

For aims of analysis a system of Cartesians coordinates was created in the n- dimension's space, which one kind of variables describing features of a given coal seam corresponds to every of axes in. It is possible to describe every of lines of the set of primary data in the form of the vector in the ndimensions space, for which coordinates of the top appoint values of individual variables for. For the entire set of primary data we will receive, so, very bulk of vectors located in this space, fastened in the beginning of the system of coordinates.

A method of concentrations and automatic

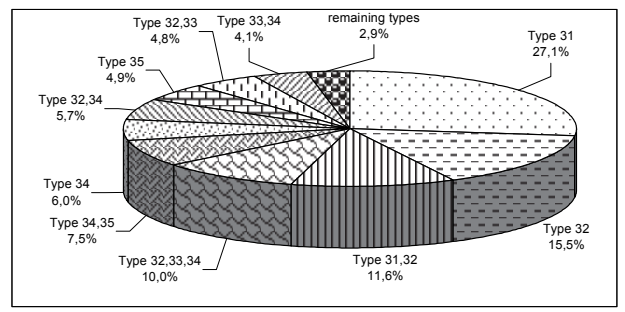

Source: own study.

Fig. 1. Structure of resources according to the criterion of types of coal neural networks were used to the further data handling $[1,4]$. The application of the method of concentrations allows for assigning subsets being characterized by resemblance of variables with reason of oneself [3]. For individual sections of analysis, from the entire set of primary data, subsets described only by analysed variables were created.

Automatic neural networks are computer programs imitating learning processes appearing in the human mind in their action. In this particular case a peculiar type of the net was exploited - Kohonena networks, and a STATISTICA program was a tool of the realization 9.0 version [2].

Primary data obtained from mines were a base of to do analyse [5].

\section{STRUCTURE OF RESOURCES ACCORDING TO THE CRITERION OF THE TYPE OF COAL}

The criterion of types of coal was applied in this diameter of analysis. It was assumed that giving a few types of coal in characteristics of resources meant that they are in these resources quoin of different types in this analysis.

According to classification in accordance with Polish Norms the following types of coal were distinguished: Type 31 - flame coal; Type 32 - fiery - flame coal; Type 33 - fiery coal; Type 34 - fiery - cooking coal; Type 35 orto - cooking coal; Type 36 - meta - cooking coal; Type 37 - semi - cooking coal.

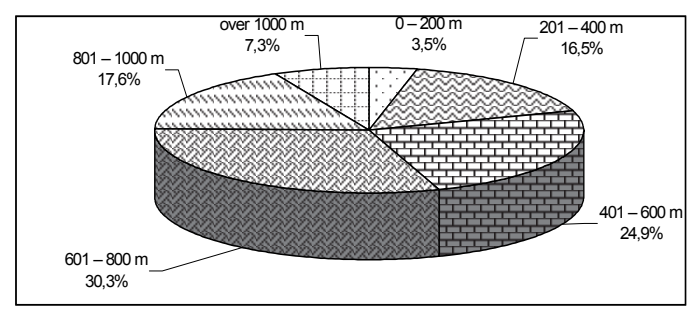

Source: own study.

Fig. 2. Structure of resources according to the criterion of the average depth of covering of coal seams 


\begin{tabular}{|l|l|l|l|}
\hline Id. & \multicolumn{1}{|c|}{ Types of coals } & \multicolumn{1}{|c|}{$\begin{array}{c}\text { Size of resources } \\
\text { [thousands of ton }\end{array}$} & \multicolumn{1}{c|}{$\begin{array}{c}\text { \% of participation in } \\
\text { resources with the whole }\end{array}$} \\
\hline 1 & Type 31 & 2946517 & 27.6 \\
\hline 2 & Type 32 & 1683001 & 15.46 \\
\hline 3 & Type 33 & 70201 & 0.64 \\
\hline 4 & Type 34 & 648717 & 5.96 \\
\hline 5 & Type 35 & 537166 & 4.93 \\
\hline 6 & Type 36 & 4202 & 0.04 \\
\hline 7 & Type 37 & 37633 & 0.35 \\
\hline 8 & Type 31,32 & 1267695 & 11.64 \\
\hline 9 & Type 32,33 & 445191 & 4.09 \\
\hline 10 & Type 32,34 & 624489 & 5.74 \\
\hline 11 & Type 32,35 & 18820 & 0.17 \\
\hline 12 & Type 33,34 & 256514 & 2.16 \\
\hline 13 & Type 33,35 & 13375 & 0.12 \\
\hline 14 & Type 34,35 & 811447 & 7.45 \\
\hline 15 & Type 35,36 & 23729 & 0.22 \\
\hline 16 & Type 35,37 & 69252 & 0.64 \\
\hline 17 & Type 36,37 & 5478 & 0.05 \\
\hline 18 & Type 31,32,33 & 30960 & 0.28 \\
\hline 19 & Type 31,32,34 & 57766 & 0.53 \\
\hline 20 & Type 32,33,34 & 1042487 & 9.57 \\
\hline 21 & Type 32,34,35 & 35494 & 0.33 \\
\hline 22 & Type 33,34,35 & 84125 & 0.77 \\
\hline 23 & Type 34,35,37 & 5475 & 0.05 \\
\hline 24 & Type 35,36,37 & 1913 & 0.02 \\
\hline 25 & Type 31,32,33,34 & 70959 & 0.65 \\
\hline 27 & Type 32,33,34,35 & 0.88 \\
\hline & TOTAL & & \\
\hline & & & \\
\hline
\end{tabular}

Source: own study.

In the Table 1 a structure of resources was given according to the criterion of types of coal. In figure 6 a structure of reserves according to the criterion of the type of coal for the whole tested resources was described.

In resources with the whole coals of the following types have large stakes: Type $31-$ 2946517 th. tone i.e. $27,06 \%$ whole of stores; Type 32 - 1683001 th. tone i.e. $15,46 \%$ whole of stores; Type $31,32-$ 1267695 th. tone i.e. the $11.64 \%$ whole of stores and the Type 32, 33, $34-1042487$ th. tone i.e. $9.57 \%$ whole of stores.
STRUCTURE OF RESOURCES ACCORDING TO THE CRITERION OF IDENTITY FOR RANGES OF THE AVERAGE DEPTH OF COVERING OF COAL SEAMS

In this diameter of analysis a criterion of identity was applied for ranges of the average depth of covering of restores. In analysis the following ranges of the average depth of covering were accepted: $0-200 \mathrm{~m}, 201-400 \mathrm{~m}$, $401-600 \mathrm{~m}, 601-800 \mathrm{~m}, 801-1000 \mathrm{~m}$, over $1000 \mathrm{~m}$.

In the Table 2 a structure of resources was given according to the criterion of identity for ranges to the depth of covering of coal seams, and in picture 2 graphically this structure of resources was described.

In resources with the whole the largest re- 
serves of coal are appearing in ranges of the average depth of covering: in the range from 601 up to $800 \mathrm{~m}-3299842$ thousands tone i.e. the
$30.31 \%$ whole of stores and in the range from 401 up to $600 \mathrm{~m}-2708947$ thousands tone i.e. $24.88 \%$.

STRUCTURE OF RESOURCES ACCORDING TO THE CRITERION OF THE AVERAGE

Table 2 DEPTH OF COVERING OF COAL SEAMS

\begin{tabular}{|c|l|l|l|}
\hline Id. & \multicolumn{1}{|c|}{ Ranges of the depth of covering } & \multicolumn{1}{|c|}{$\begin{array}{c}\text { Size of resources } \\
{[\text { thousands of ton }]}\end{array}$} & $\begin{array}{c}\text { \% of participation in re- } \\
\text { sources with the whole }\end{array}$ \\
\hline 1 & $0-200 \mathrm{~m}$ & 381258 & 3.50 \\
\hline 2 & $201-400 \mathrm{~m}$ & 1791386 & 16.45 \\
\hline 3 & $401-600 \mathrm{~m}$ & 2708947 & 24.88 \\
\hline 4 & $601-800 \mathrm{~m}$ & 3299842 & 30.31 \\
\hline 5 & $801-1000 \mathrm{~m}$ & 1910948 & 17.55 \\
\hline 6 & over $1000 \mathrm{~m}$ & 795938 & 7.31 \\
\hline & TOTAL & 10888319 & \\
\hline
\end{tabular}

Source: own study.

STRUCTURE OF RESOURCES ACCORDING TO THE CRITERION OF THE MEDIUM THICKNESS OF COAL SEAMS

In this diameter of analysis a criterion of ranges of the medium thickness of coal seams was applied. The following ranges of the medium thickness of seams were accepted: 0.6 up to $0.8 \mathrm{~m} ; 0.81$ to $1.0 \mathrm{~m} ; 1.01$ up to $1.2 \mathrm{~m} ; 1.21$ up to $1.4 \mathrm{~m} ; 1.41$ to $1.6 \mathrm{~m}$ and above $1.6 \mathrm{~m}$. In the range resources above of the average thicknesses $1.6 \mathrm{~m}$ are finding underground oneself resources about the variable of thicknesses, in which the lower limit of the thickness is located in a range 0.6 up to $1.6 \mathrm{~m}$.

In Table 3 a structure of sources was given according to the criterion of ranges to the medium thickness of decks, and in Figure 3 a graphical illustration of this structure was described.

STRUCTURE OF RESOURCES ACCORDING TO THE CRITERION OF RANGES |

Table 3

\section{OF THE MEDIUM THICKNESS OF COAL SEAMS}

\begin{tabular}{|c|l|l|l|}
\hline Id. & $\begin{array}{c}\text { Ranges of the medium thickness } \\
\text { of coal seams }\end{array}$ & \multicolumn{1}{|c|}{$\begin{array}{c}\text { Size of resources } \\
\text { [thousands of ton] }\end{array}$} & $\begin{array}{c}\text { \% of participation in } \\
\text { resources with the whole }\end{array}$ \\
\hline 1 & 0.6 to $0.8 \mathrm{~m}$ & 821037 & 7.54 \\
\hline 2 & 0.81 to $1.0 \mathrm{~m}$ & 4120405 & 37.84 \\
\hline 3 & 1.01 to $1.2 \mathrm{~m}$ & 3492662 & 32.08 \\
\hline 4 & 1.21 to $1.4 \mathrm{~m}$ & 1577880 & 14.49 \\
\hline 5 & 1.41 to $1.6 \mathrm{~m}$ & 500760 & 4.60 \\
\hline 6 & over $1.6 \mathrm{~m}$ & 375575 & 3.45 \\
\hline & TOTAL & 10888319 & \\
\hline
\end{tabular}

Source: own study

The largest resources of coal are located in ranges of the medium thickness of seams: in the range 0,81 to $1,0 \mathrm{~m}-4120405$ thousand of ton that presents $37,84 \%$ of whole of re- sources and in the range 1,01 up to $1,2 \mathrm{~m}-$ 3492662 thousand of ton that presents $32,08 \%$ of whole of resources. 
THE STRUCTURE OF RESOURCES ACCORDING TO CRITERION OF THE AVERAGE INCLINATION OF COAL SEAMS

It was applied a criterion of ranges of average inclination of coal seams as well as the resources selection into the capital groups and then its division into the particular coal mines that are within those groups in this diameter of analysis .

The following ranges of average inclination of seams were accepted: $0^{\circ}$ to $5^{\circ} ; 6^{\circ}$ to $10^{\circ}$; $11^{\circ}$ to $15^{\circ} ; 16^{\circ}$ to $20^{\circ} ; 21^{\circ}$ to $25^{\circ}$; above $25^{\circ}$.

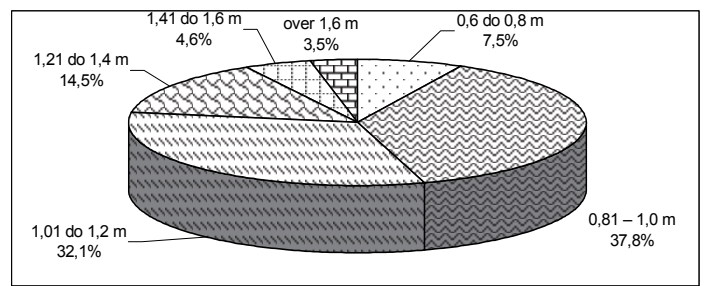

Source: own study.

Fig. 3. Structure of resources according to the criterion of ranges of the medium thickness of coal seams.
In Table 4 a structure of resources was given according to the criterion of ranges of average inclination of coal seams, and in Figure 4 a graphical illustration of this structure was described.

The largest coal resources are located in range of average inclination of seams: in range $0^{\circ}$ to $5^{\circ}-4559024$ thousand tone i.e. the $41.87 \%$ whole of stores and in range $6^{\circ}$ to $10^{\circ}-3829225$ thousand tone i.e. the $35.17 \%$ whole of stores.

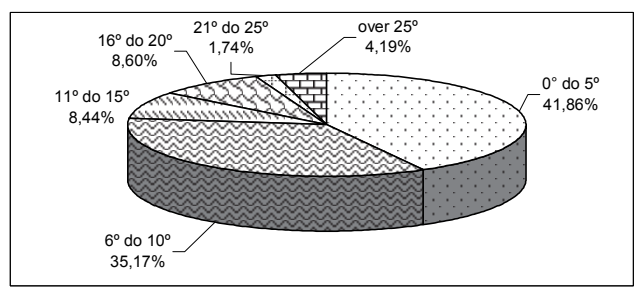

Source: own study.

Fig. 4. The structure of resources according to criterion of ranges the average inclination of coal seams.

STRUCTURE OF RESOURCES ACCORDING TO THE CRITERION OF RANGES OF

Table 4 AVERAGE INCLINATION COAL-SEAMS

\begin{tabular}{|c|l|l|l|}
\hline Id. & \multicolumn{1}{|c|}{$\begin{array}{c}\text { Ranges of average inclination of } \\
\text { coal seams }\end{array}$} & \multicolumn{1}{|c|}{$\begin{array}{c}\text { Size of resources } \\
\text { [thousands of ton] }\end{array}$} & $\begin{array}{c}\text { \% of participation in } \\
\text { resources as total }\end{array}$ \\
\hline 1 & $0^{\circ}$ to $5^{\circ}$ & 4559024 & 41.86 \\
\hline 2 & $6^{\circ}$ to $10^{\circ}$ & 3829225 & 35.17 \\
\hline 3 & $11^{\circ}$ to $15^{\circ}$ & 918671 & 8.44 \\
\hline 4 & $16^{\circ}$ to $20^{\circ}$ & 936025 & 8.60 \\
\hline 5 & $21^{\circ}$ to $25^{\circ}$ & 189195 & 1.74 \\
\hline 6 & above $25^{\circ}$ & 456179 & 4.19 \\
\hline & SUM & 10888319 & \\
\hline
\end{tabular}

Source: own study. 
STRUCTURE OF RESOURCES ACCORDING TO ASSOCIATIVE CRITERIA OF THE AVERAGE DEPTH OF COVERING AND THE MEDIUM THICKNESS OF COAL SEAMS

It was applied the associative criteria of the average depth of covering of coal seams and the average of thickness of these seams as well as the resources selection into the capital groups and then its division into the particular coal mines that are within those groups in this diameter of analysis. The following ranges of the average depth of covering of seams were accepted: 0 up to $200 \mathrm{~m} ; 201$ up to $400 \mathrm{~m}$; 401 up to $600 \mathrm{~m} ; 601$ up to $800 \mathrm{~m} ; 801$ up to $1000 \mathrm{~m}$; over $1000 \mathrm{~m}$.

The following ranges of the medium thickness of coal seams were accepted: 0,6 up to $0,8 \mathrm{~m} ; 0,81$ up to $1.0 \mathrm{~m} ; 1,01$ up to $1,2 \mathrm{~m}$; 1,21 up to $1.4 \mathrm{~m} ; 1,41$ to $1,6 \mathrm{~m}$ and the over $1,6 \mathrm{~m}$. The seam of the thickness over 1,6 m were ranked among thin coal seams about the diversified thickness, which the lower limit of the thickness is located in a range from 0,6 up to $1,6 \mathrm{~m}$.

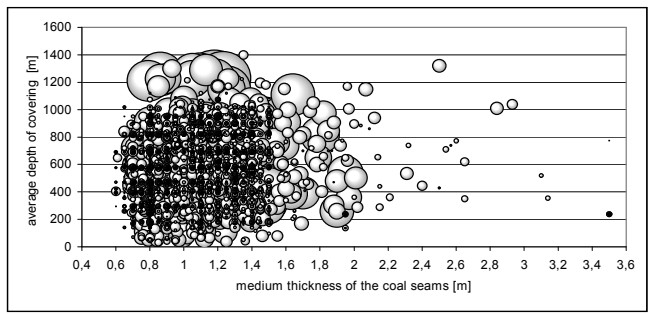

Source: own study.

Fig. 5. Structure of resources according to associative criteria of ranges of the average depth of covering and ranges of the average of thickness of seams appointed according to real values

The structure of resources according to the associative criterion of ranges to the medium thickness and the average depths of covering of stores was given in Table 5. The illustration of structure of resources appointed according to real values was showed on Figure 5 and on Figure 6 appointed according to ranges of value.

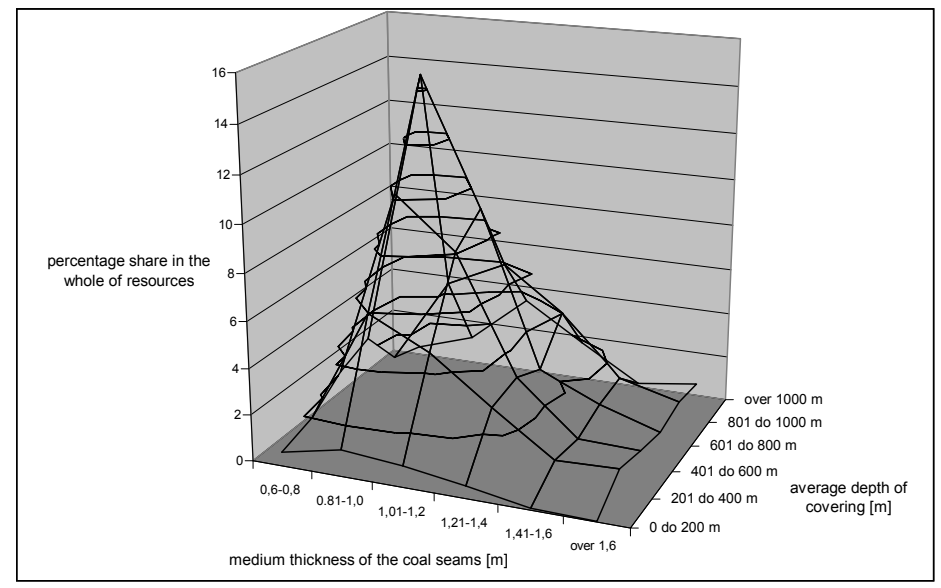

Source: own study.

Fig. 6. Structure of resources according to associative criteria of ranges of the average depth of covering and ranges of the average of thickness of coal seams appointed according to ranges of value 
THE STRUCTURE OF RESOURCES ACCORDING TO ASSOCIATIVE CRITERIA OF RANGES

Table 5

\section{OF AVERAGE DEPTH COVERING AS WELL AS THE RANGES OF AVERAGE OF THICKNESS SEAMS}

\begin{tabular}{|l|l|l|l|l|l|l|l|}
\hline $\begin{array}{l}\text { Ranges of the } \\
\text { average depth } \\
\text { of covering of } \\
\text { seams }\end{array}$ & $0.6-0.8$ & $0.81-1.0$ & $1.01-1.2$ & $1.21-1.4$ & $1.41-1.6$ & over 1.6 & \\
\cline { 2 - 8 } & \multicolumn{7}{|c|}{ Absolute values [thousands of ton] } \\
\hline \multicolumn{7}{|c|}{} \\
\hline 0 to $200 \mathrm{~m}$ \\
\hline 201 to $400 \mathrm{~m}$ & 114000 & 650579 & 509224 & 301317 & 102503 & 113763 & 2712548 \\
\hline 401 to $600 \mathrm{~m}$ & 227235 & 1113775 & 879427 & 332538 & 83671 & 75902 & 3314569 \\
\hline 601 to $800 \mathrm{~m}$ & 228071 & 1590812 & 997034 & 260852 & 134432 & 43368 & 375575 \\
\hline 801 to $1000 \mathrm{~m}$ & 87468 & 509240 & 641519 & 439086 & 153989 & 79646 & 1910948 \\
\hline over $1000 \mathrm{~m}$ & 37664 & 129368 & 365153 & 185701 & 16173 & 58278 & 792337 \\
\hline SUM & 821037 & 4120404 & 3492662 & 1577880 & 500760 & 375576 & 10888319 \\
\hline & \multicolumn{7}{|c|}{ Percentage share in the whole of resources } \\
\hline 0 to $200 \mathrm{~m}$ & 0.61 & 1.16 & 0.92 & 0.54 & 0.09 & 0.04 & 3.36 \\
\hline 201 to $400 \mathrm{~m}$ & 1.05 & 5.98 & 4.68 & 2.77 & 0.94 & 1.04 & 16.46 \\
\hline 401 to $600 \mathrm{~m}$ & 2.09 & 10.22 & 8.08 & 3.05 & 0.77 & 0,70 & 24.91 \\
\hline 601 to $800 \mathrm{~m}$ & 2.65 & 14.61 & 9.16 & 2.40 & 1.23 & 0.40 & 30.45 \\
\hline 801 to $1000 \mathrm{~m}$ & 0.80 & 4.68 & 5.88 & 4.03 & 1.41 & 0.73 & 17.53 \\
\hline over $1000 \mathrm{~m}$ & 0.35 & 1.19 & 3.35 & 1.71 & 0.15 & 0.54 & 7.29 \\
\hline SUM & 7.55 & 37.84 & 32.07 & 14.50 & 4.19 & 3.45 & 100 \\
\hline
\end{tabular}

Source: own study.

The largest resources of coal are located in the ranges of the medium thickness of coal seams and the average depths of covering: in the range of the thickness 0.81 up to $1.0 \mathrm{~m}$ and the range of the depth of covering 601 to $800 \mathrm{~m}-1590812$ thousand ton i.e. the $14.61 \%$ whole of stores.

\section{STRUCTURE OF RESOURCES ACCORDING TO ASSOCIATIVE CRITERIA OF THE AVERAGE DEPTH OF COVERING, OF THE MEDIUM CALORIFIC VALUE AND THE AVERAGE CONTENT OF SULPHUR}

It was applied the associative criteria of the average depth of covering of coal seams, of the medium calorific value and the average content of sulphur in as well as the resources selection into the capital groups and then its division into the particular coal mines that are within those groups in this diameter of analysis.

The following ranges of the average depth of covering of coal seams were accepted: 0 up to $200 \mathrm{~m} ; 201$ up to $400 \mathrm{~m} ; 401$ up to $600 \mathrm{~m} ; 601$ up to $800 \mathrm{~m}$; 801 up to $1000 \mathrm{~m}$; over $1000 \mathrm{~m}$. The following ranges of the medium calorific value were accepted: to $18,0 \mathrm{~kJ} / \mathrm{kg} ; 18,01$ to
$22,0 \mathrm{~kJ} / \mathrm{kg} ; 22,01$ to $26,0 \mathrm{~kJ} / \mathrm{kg} ; 26,01$ to 30,0 $\mathrm{kJ} / \mathrm{kg}$ and above $30,0 \mathrm{~kJ} / \mathrm{kg}$.

The following ranges of the average content of sulphur were accepted: to $0,4 \% ; 0,41$ to $1,0 \% ; 1,01$ to $1,6 \% ; 1,61$ to $2,2 \%$ and above $2,20 \%$.

The structure of resources for the whole of stores according to the associative criterion of ranges to the average depth of lying of decks, for the medium calorific value and the average content of sulphur was given in Table 6 .

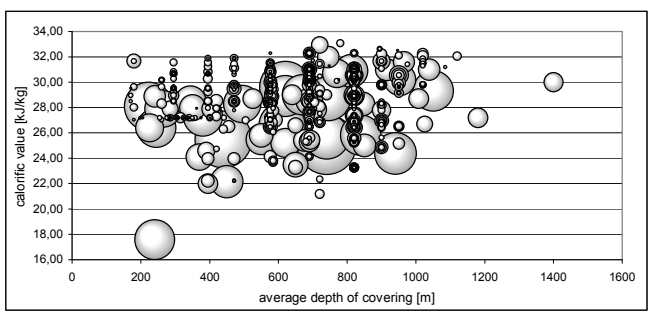

Source: own study.

Fig. 7. Structure of resources according to associative criteria of the average depth of covering and the medium calorific value appointed according to real values - for the content of sulphur in coal to $0.4 \%$ 


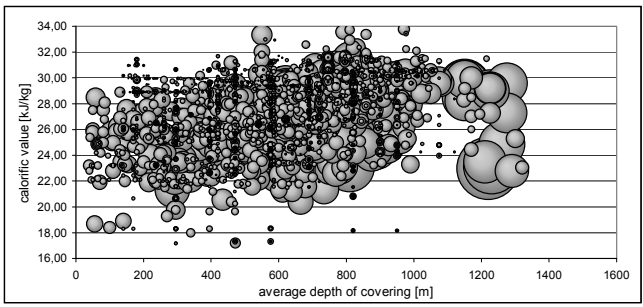

Source: own study.

Fig. 8. Structure of resources according to associative criteria of the average depth of covering and the medium calorific value appointed according to real values - for the content of sulphur in coal from 0.41 to $1.0 \%$

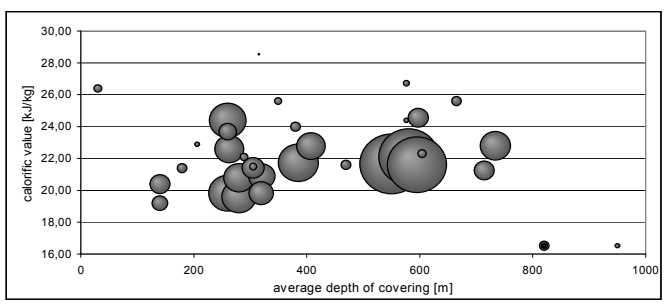

Source: own study.

Fig. 10. Structure of resources according to associative criteria of the average depth of covering and the medium calorific value appointed according to real values - for the content of sulphur in coal from 1.61 to $2.2 \%$

Structure of resources was set according to real values, based on adopted criteria, for stores with the whole, for different ranges contents of sulphur were described appropriately: on Figure 7 - for the range to $0,4 \%$; on Figure $8-$ for the range from 0,41 to $1.0 \%$; on Figure $9-$ for the range from 1,01 to $1,6 \%$; on Figure $10-$ for the range 1,61 to 2,2\% and on Figure 11 for the content above $2,21 \%$.

The complete resources of coals with the content of sulphur meeting the appropriate ranges, representing the following participations : to $0,40 \%-3,801 \%$ i.e. 414031 thousands of ton; from 0,41 to $1,0 \%-71,266 \%$ i.e. 7759061 thousands of ton; from 1,01 to $1,6 \%-9.263 \%$ i.e. 2094835 thousands of ton; from 1,61 to $2,2 \%-3,787 \%$ i.e. 411411 thousands of ton; above $2,2 \%-1,882 \%$ i.e. 208981 thousands of ton.

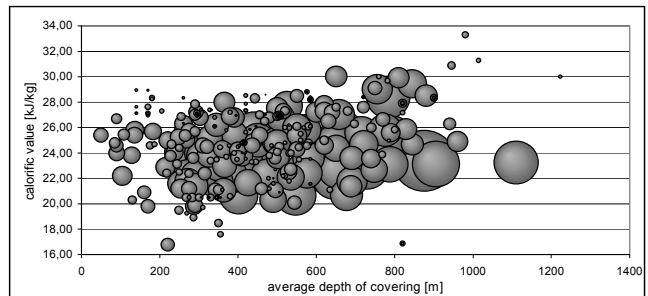

Source: own study.

Fig. 9. Structure of resources according to associative criteria of the average depth of covering and the medium calorific value appointed according to real values - for the content of sulphur in coal from 1.01 to $1.6 \%$

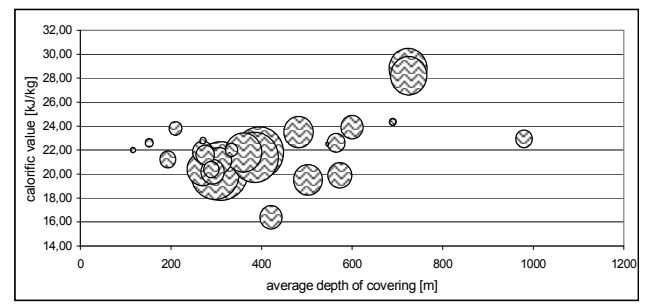

Source: own study.

Fig. 11. Structure of resources according to associative criteria of the average depth of covering and the medium calorific value appointed according to real values - for the content of sulphur in coal above $2.2 \%$

The complete resources of the coals with the calorific value meeting the appropriate ranges representing the following participations: to $18 \mathrm{~kJ} / \mathrm{kg}-0.439 \%$ i.e. 47043 thousands of ton; from 18,01 to $22,0 \mathrm{~kJ} / \mathrm{kg}$ $7,373 \%$ i.e. 802182 thousands of ton; from 22,01 to $26,0 \mathrm{~kJ} / \mathrm{kg}-44,306 \%$ i.e. 4826010 thousands of ton; from 26,01 to $30,0 \mathrm{~kJ} / \mathrm{kg}-$ $42,257 \%$ i.e. 4600054 thousands of ton; above $30,0 \mathrm{~kJ} / \mathrm{kg}-5,624 \%$ i.e. 613030 thousands of ton.

The maximum participation in the whole of resources carrying out 13,19\% i.e. 1436642 thousand tons possess the resources fulfilling the following criteria: the content of sulphur the range from 0,41 to $1,0 \%$; calorific value in range from 26,01 to $30,0 \mathrm{~kJ} / \mathrm{kg}$ as well as depth of covered in range since 601 to $800 \mathrm{~m}$. 
STRUCTURE OF RESOURCES ACCORDING TO ASSOCIATIVE CRITERIA OF RANGES

Table 6 (a)

OF THE AVERAGE DEPTH OF COVERING OF COAL SEAMS, RANGES OF THE MEDIUM

CALORIFIC VALUE AND RANGES OF THE AVERAGE CONTENT OF SULPHUR - REAL VALUE

\begin{tabular}{|c|c|c|c|c|c|c|}
\hline \multirow{2}{*}{$\begin{array}{l}\text { Ranges of the average } \\
\text { depth of coal seams }\end{array}$} & \multicolumn{5}{|c|}{ Ranges of medium calorific values $[\mathrm{kJ} / \mathrm{kg}]$} & \multirow[t]{2}{*}{ SUM } \\
\hline & to 18.0 & $18.01-22.0$ & $22.01-26.0$ & $26.01-30.0$ & over 30.0 & \\
\hline \multicolumn{7}{|c|}{ Absolute values [thousands of ton] } \\
\hline \multicolumn{7}{|c|}{ Content of sulphur to $0.4 \%$} \\
\hline 0 to $200 \mathrm{~m}$ & 0 & 0 & 0 & 795 & 1029 & 1824 \\
\hline 201 to $400 \mathrm{~m}$ & 7205 & 0 & 7958 & 51961 & 3501 & 70625 \\
\hline 401 to $600 \mathrm{~m}$ & 0 & 0 & 29068 & 40385 & 6215 & 75668 \\
\hline 601 to $800 \mathrm{~m}$ & 359 & 0 & 40796 & 86381 & 22231 & 149767 \\
\hline 801 to $1000 \mathrm{~m}$ & 0 & 0 & 27412 & 35155 & 34294 & 96861 \\
\hline over $1000 \mathrm{~m}$ & 0 & 0 & 0 & 14765 & 4521 & 19286 \\
\hline SUM & 7564 & $\mathbf{0}$ & 105234 & 229442 & 71791 & 414031 \\
\hline & \multicolumn{6}{|c|}{ Content of sulphur from 0.41 to $1.0 \%$} \\
\hline 0 to $200 \mathrm{~m}$ & 21390 & 0 & 150094 & 109751 & 3003 & 284238 \\
\hline 201 to $400 \mathrm{~m}$ & 1746 & 66949 & 633341 & 225984 & 3335 & 931355 \\
\hline 401 to $600 \mathrm{~m}$ & 3729 & 30901 & 811865 & 772411 & 50173 & 1669079 \\
\hline 601 to $800 \mathrm{~m}$ & 0 & 61804 & 807316 & 1436642 & 219145 & 2524907 \\
\hline 801 to $1000 \mathrm{~m}$ & 0 & 5141 & 343304 & 1040425 & 225986 & 1614856 \\
\hline over $1000 \mathrm{~m}$ & 0 & 0 & 252743 & 453791 & 28092 & 734626 \\
\hline \multirow[t]{2}{*}{ SUM } & 26865 & 164795 & 2998663 & 4039004 & 529734 & 7759061 \\
\hline & \multicolumn{6}{|c|}{ Content of sulphur from 1,01 to $1.6 \%$} \\
\hline 0 to $200 \mathrm{~m}$ & 0 & 8839 & 49573 & 5249 & 0 & 63661 \\
\hline 201 to $400 \mathrm{~m}$ & 4303 & 114902 & 308134 & 59163 & 0 & 486502 \\
\hline 401 to $600 \mathrm{~m}$ & 0 & 131210 & 510559 & 83504 & 0 & 725273 \\
\hline 601 to $800 \mathrm{~m}$ & 0 & 82262 & 383555 & 112732 & 9000 & 587549 \\
\hline 801 to $1000 \mathrm{~m}$ & 640 & 0 & 148367 & 42358 & 2059 & 193424 \\
\hline over $1000 \mathrm{~m}$ & 0 & 0 & 37752 & 228 & 446 & 38426 \\
\hline \multirow[t]{2}{*}{ SUM } & 4943 & 337213 & 1437940 & 30323 & 11505 & 2094835 \\
\hline & \multicolumn{6}{|c|}{ Content of sulphur from 1.61 to $2.2 \%$} \\
\hline 0 to $200 \mathrm{~m}$ & 0 & 12425 & 0 & 1087 & 0 & 13512 \\
\hline 201 to $400 \mathrm{~m}$ & 0 & 0 & 161694 & 42 & 0 & 161736 \\
\hline 401 to $600 \mathrm{~m}$ & 0 & 127259 & 80385 & 586 & 0 & 208230 \\
\hline 601 to $800 \mathrm{~m}$ & 0 & 6823 & 18064 & 0 & 0 & 24887 \\
\hline 801 to $1000 \mathrm{~m}$ & 3046 & 0 & 0 & 0 & 0 & 3046 \\
\hline \multirow[t]{2}{*}{ SUM } & 3046 & 146507 & 260143 & 1715 & $\mathbf{0}$ & 411411 \\
\hline & \multicolumn{6}{|c|}{ Content of sulphur above $2.2 \%$} \\
\hline 0 to $200 \mathrm{~m}$ & 0 & 2688 & 608 & 0 & 0 & 3296 \\
\hline 201 to $400 \mathrm{~m}$ & 0 & 137611 & 3557 & 0 & 0 & 141168 \\
\hline 401 to $600 \mathrm{~m}$ & 4625 & 13386 & 16304 & 0 & 0 & 34297 \\
\hline 601 to $800 \mathrm{~m}$ & 0 & 0 & 800 & 26659 & 0 & 27459 \\
\hline 801 to $1000 \mathrm{~m}$ & 0 & 0 & 2761 & 0 & 0 & 2761 \\
\hline SUM & 4625 & 153667 & 24030 & 26659 & $\mathbf{0}$ & 208981 \\
\hline TOTAL & 47043 & 802182 & 4826010 & 4600054 & 613030 & 10888319 \\
\hline
\end{tabular}

Source: own study. 
STRUCTURE OF RESOURCES ACCORDING TO ASSOCIATIVE CRITERIA OF RANGES

Table $6(b)$ OF THE AVERAGE DEPTH OF COVERING OF COAL SEAMS, RANGES OF THE MEDIUM CALORIFIC VALUE AND RANGES OF THE AVERAGE CONTENT OF SULPHUR PERCENTAGE SHARES

\begin{tabular}{|c|c|c|c|c|c|c|}
\hline \multirow{2}{*}{$\begin{array}{l}\text { Ranges of the } \\
\text { average depth of } \\
\text { coal seams }\end{array}$} & \multicolumn{5}{|c|}{ Ranges of medium calorific values $[\mathrm{kJ} / \mathrm{kg}]$} & \multirow[t]{2}{*}{ SUM } \\
\hline & to 18.0 & $18.01-22.0$ & $22.01-26.0$ & $26.01-30.0$ & $\begin{array}{l}\text { over } \\
30.0\end{array}$ & \\
\hline \multicolumn{7}{|c|}{ Percentage shares in the whole of resources } \\
\hline & \multicolumn{6}{|c|}{ Content of sulphur to $0.4 \%$} \\
\hline 0 to $200 \mathrm{~m}$ & 0 & 0 & 0 & 0.0073 & 0.0095 & 0.017 \\
\hline 201 to $400 \mathrm{~m}$ & 0.07 & 0 & 0.073 & 0.48 & 0.0322 & 0.655 \\
\hline 401 to $600 \mathrm{~m}$ & 0 & 0 & 0.27 & 0.37 & 0.0571 & 0.698 \\
\hline 601 to $800 \mathrm{~m}$ & 0.003 & 0 & 0.375 & 0.793 & 0.20 & 1.371 \\
\hline 801 to $1000 \mathrm{~m}$ & 0 & 0 & 0.25 & 0.32 & 0.31 & 0.880 \\
\hline over $1000 \mathrm{~m}$ & 0 & 0 & 0 & 0.14 & 0.04 & 0.180 \\
\hline \multirow[t]{2}{*}{ SUM } & 0.073 & 0.000 & 0.968 & 2.111 & 0.649 & 3.801 \\
\hline & \multicolumn{6}{|c|}{ Content of sulphur from 0.41 to $1.0 \%$} \\
\hline 0 to $200 \mathrm{~m}$ & 0.20 & 0 & 1.38 & 1.01 & 0.028 & 2.618 \\
\hline 201 to $400 \mathrm{~m}$ & 0.016 & 0.61 & 5.82 & 2.08 & 0.031 & 8.557 \\
\hline 401 to $600 \mathrm{~m}$ & 0.034 & 0.28 & 7.46 & 7.09 & 0.46 & 15.324 \\
\hline 601 to $800 \mathrm{~m}$ & 0 & 0.57 & 7.41 & 13.19 & 2.01 & 23.180 \\
\hline 801 to $1000 \mathrm{~m}$ & 0 & 0.047 & 3.15 & 9.56 & 2.08 & 14.837 \\
\hline over $1000 \mathrm{~m}$ & 0 & 0 & 2.32 & 4.17 & 0.26 & 6.750 \\
\hline \multirow[t]{2}{*}{ SUM } & 0.250 & 1.507 & 27.54 & 37.1 & 4.869 & 71.266 \\
\hline & \multicolumn{6}{|c|}{ Content of sulphur from 1.01 to $1.6 \%$} \\
\hline 0 to $200 \mathrm{~m}$ & 0 & 0.081 & 0.46 & 0.048 & 0 & 0.589 \\
\hline 201 to $400 \mathrm{~m}$ & 0.04 & 1.06 & 2.83 & 0.54 & 0 & 4.470 \\
\hline 401 to $600 \mathrm{~m}$ & 0 & 1.21 & 4.69 & 0.77 & 0 & 6.670 \\
\hline 601 to $800 \mathrm{~m}$ & 0 & 0.76 & 3.52 & 1.04 & 0.083 & 5.403 \\
\hline 801 to $1000 \mathrm{~m}$ & 0.006 & 0 & 1.36 & 0.39 & 0.019 & 1.775 \\
\hline over $1000 \mathrm{~m}$ & 0 & 0 & 0.35 & 0.0021 & 0.0041 & 0.356 \\
\hline \multirow[t]{2}{*}{ SUM } & 0.046 & 3.111 & 13.210 & 2.790 & 0.106 & 19.263 \\
\hline & \multicolumn{6}{|c|}{ Content of sulphur from 1,61 to $2,2 \%$} \\
\hline 0 to $200 \mathrm{~m}$ & 0 & 0.114 & 0 & 0.010 & 0 & 0.124 \\
\hline 201 to $400 \mathrm{~m}$ & 0 & 0 & 1.49 & 0.00039 & 0 & 1.490 \\
\hline 401 to $600 \mathrm{~m}$ & 0 & 1.17 & 0.74 & 0.0054 & 0 & 1.915 \\
\hline 601 to $800 \mathrm{~m}$ & 0 & 0.063 & 0.166 & 0 & 0 & 0.229 \\
\hline 801 to $1000 \mathrm{~m}$ & 0.028 & 0 & 0 & 0 & 0 & 0.028 \\
\hline \multirow[t]{2}{*}{ SUM } & 0.028 & 1.347 & 2.396 & 0.016 & 0.000 & 3.787 \\
\hline & \multicolumn{6}{|c|}{ Content of sulphur above $2.2 \%$} \\
\hline 0 to $200 \mathrm{~m}$ & 0 & 0.025 & 0.0056 & 0 & 0 & 0.031 \\
\hline 201 to $400 \mathrm{~m}$ & 0 & 1,26 & 0.0033 & 0 & 0 & 1.263 \\
\hline 401 to $600 \mathrm{~m}$ & 0.042 & 0.123 & 0.151 & 0 & 0 & 0.316 \\
\hline 601 to $800 \mathrm{~m}$ & 0 & 0 & 0.0073 & 0.24 & 0 & 0.247 \\
\hline 801 to $1000 \mathrm{~m}$ & 0 & 0 & 0.025 & 0 & 0 & 0.025 \\
\hline SUM & 0.042 & 1.408 & 0.192 & 0.240 & 0.000 & 1.882 \\
\hline TOTAL & 0.439 & 7.373 & 44.306 & 42.257 & 5.624 & 100.00 \\
\hline
\end{tabular}

Source: own study. 


\section{CONCLUSIONS}

The analysis of characteristic feature of coal seams, covering in Poland in thin seams, show that they are then the resources, in majority, very attractive to future exploitation. It is possible even to propose a thesis, that they are more attractive than, many thin coal seams exploited for decades in the Ukraine. The mining of Ukraine, with success, exploits such coal seams, then it is logic that it should also be back to their mining utilization in Poland.

\section{REFERENCES}

1. Cichosz, P. 2000. Systemy uczace się. Warszawa: WNT.

2. Dokumentacja programu. 2010. STATISTICA v. 9.0.

3. Everitt, B.S., Landau, S. \& Leese, M. 2001. - Cluster analysis. Londyn, Arnold, New York, Oxford: University Press.

4. Tadeusiewicz, R. 1993. Sieci neuronowe. Warszawa: AOW RW.5
5. Materiały źródłowe Kompanii Węglowej S.A., Katowickiego Holdingu Węglowego S.A., Jastrzębskiej Spótki Węglowej S.A. oraz Południowego Koncernu Węglowego. 2010.

\section{ABOUT AUTHORS}

Andzej Krowiak - professor Glowny Instytut Gornictwa. 